\title{
POTENSI INHIBITOR KATEPSIN DARI DUA SPESIES DAN SATU HIBRID KULIT IKAN PATIN DALAM MENGHAMBAT AKTIVITAS KATEPSIN IKAN PATIN SIAM
}

\section{Potency of Cathepsin Inhibitor from Two Species and One Hybrid of Catfish Skin on Inhibition of Cathepsin Activity of Siam Catfish}

\author{
Tati Nurhayati ${ }^{1^{*}}$, Ekowati Chasanah², dan Saeful Bahri ${ }^{1}$ \\ ${ }^{1}$ Departemen Teknologi Hasil Perairan, Fakultas Perikanan dan IImu Kelautan, Institut Pertanian Bogor. \\ JI. Lingkar Akademik, Kampus IPB Darmaga Bogor \\ ${ }^{2}$ Balai Besar Penelitian dan Pengembangan Pengolahan Produk dan Bioteknologi Kelautan dan Perikanan, KKP. \\ JI.K.S. Tubun Petamburan VI, Jakarta Pusat 10260 \\ * Korespondensi Penulis: nurhayati7870@yahoo.com
}

Diterima: 3 Maret 2013 Disetujui: 25 Oktober 2013

\begin{abstract}
ABSTRAK
Proses kemunduran mutu ikan dapat disebabkan oleh adanya aktivitas enzim terutama enzim proteolitik, salah satunya adalah katepsin yang merupakan kelompok protease sistein. Protease sistein merupakan kelompok enzim pendegradasi protein. Untuk mencegah terjadinya proteolisis yang destruktif yang berakibat pada besarnya losses ikan segar, inhibitor untuk katepsin sangat dibutuhkan. Tujuan penelitian ini adalah untuk mengetahui potensi kulit ikan patin Siam, Jambal, dan Pasupati sebagai sumber inhibitor katepsin, serta memekatkan dan mengkarakterisasi inhibitor katepsin yang diperoleh. Hasil penelitian menunjukkan bahwa ketiga jenis kulit ikan patin memiliki aktivitas penghambatan terhadap katepsin, tetapi yang memiliki penghambatan terbaik adalah yang berasal dari ikan patin jenis Siam dengan nilai persentase penghambatan sebesar $74,67 \%$. Hal ini diduga karena kesesuaian substrat dengan inhibitornya Pemekatan menggunakan ammonium sulfat $70 \%$ menunjukkan adanya peningkatan aktivitas penghambatan spesifik sebesar $1,4479 \mathrm{U} / \mathrm{mg}$ dengan kelipatan pemurnian sebesar 2,77 kali. Inhibitor enzim katepsin tersebut secara optimum bekerja pada suhu $40{ }^{\circ} \mathrm{C}$ dan $\mathrm{pH} 8$.
\end{abstract}

KATAKUNCl: $\quad$ ikan patin, katepsin, inhibitor protease, karakterisasi

\begin{abstract}
Fish deterioration can be caused by the activity of enzyme, especially proteolytic enzymes, one of which is chatepsin classified as cysteine proteases. Cysteine proteases are a group of enzymes that degrade proteins. To prevent destructive proteolysis and minimizing fish losses, cathepsin inhibitors is urgently needed. The purpose of this study was to determine Siam, Jambal, and Pasupati skin as a potential source of cathepsin inhibitors. The study was also intended to concentrate and characterize the obtained cathepsin inhibitors. The three catfish skin have inhibitory activity against cathepsin, however the result showed that the best inhibitor was derived from Siam catfish skin with inhibition percentage of $74.67 \%$. It is presumably due to the suitability of the enzyme with the inhibitor. Concentration using $70 \%$ ammonium sulphate showed an increase in the specific inhibitory activity of $1.4479 \mathrm{U} / \mathrm{mg}$ with purification fold of 2.77 times. Inhibitors of the chatepsin enzyme exhibited optimum activity at $40{ }^{\circ} \mathrm{C}$ and $\mathrm{pH} 8$.
\end{abstract}

KEYWORDS: $\quad$ catfish, cathepsin, protease inhibitors, characterization

\section{PENDAHULUAN}

Proses kemunduran mutu ikan disebabkan oleh adanya aktivitas enzim terutama enzim proteolitik yang secara alami terdapat dalam ikan. Enzim tersebut bekerja menguraikan protein menjadi pepton, peptida, dan asam amino. Proses hidrolisis protein oleh suatu protease misalnya katepsin, kalpain, dan kolagenase,mengakibatkan akumulasi metabolit, perubahan cita rasa dan pelunakan tekstur, terbentuknya komponen volatil, serta tersedianya asam amino sebagai sumber makanan bakteri, yang akhirnya menimbulkan kebusukan. 
Diantara ketiga jenis protease yang terlibat dalam kemunduran mutu ikan, katepsin merupakan enzim yang paling bertanggung jawab terhadap kemunduran mutu ikan (Huss, 1995). Katepsin ditemukan di lisosom serat daging dan di sel fagosit. Lisosom merupakan organel intraseluler yang banyak mengandung enzim hidrolitik dan berperan dalam pencernaan dalam sel. Beberapa tipe katepsin telah diidentifikasi berdasarkan pada kandungan asam amino yang berbeda di sisi aktifnya. Katepsin $B$ (EC 3.4.22.2) dan katepsin L (EC 3.4.22.15) merupakan proteinase sistein yang paling penting dalam kemunduran tekstur daging. Aktivitasnya berbedabeda tiap fraksi daging dan spesies ikan. Aktivitas optimum dilaporkan pada suhu $40-50{ }^{\circ} \mathrm{C}$ dan aktivitasnya menurun dengan penurunan suhu. Katepsin secara umum bekerja pada $\mathrm{pH} 3-4$ dan beberapa katepsin juga mempunyai aktivitas tinggi pada pH 6-6,5 (Kolodziejska \& Sikorski, 1996; Aoki et al., 2000).

Beberapa penelitian menunjukkan bahwa terdapat korelasi yang erat antara aktifnya enzim katepsin dengan laju kemunduran mutu ikan, baik pada bagian daging ikan (Salamah et al., 2010), jeroan ikan (Nurhayati et al., 2010'), maupun kulit ikan (Nurhayati et al., 2010 ${ }^{\mathrm{b}}$ ). Enzim tersebut tidak aktif pada saat ikan dalam kondisi segar (fase pre rigor) karena pada kondisi tersebut inhibitor katepsin bekerja untuk menghambat kerja enzim katepsin. Ketika ikan memasuki fase rigor mortis aktivitas enzim katepsin meningkat dan sangat aktif ketika ikan berada pada fase awal post rigor. Pada kondisi ini inhibitor katepsin mengalami denaturasi akibat $\mathrm{pH}$ yang rendah sehingga tidak bisa menghambat kerja enzim katepsin. $\mathrm{pH}$ rendah merupakan $\mathrm{pH}$ optimum untuk aktivitas enzim katepsin (Huss, 1995).

Salah satu cara untuk menghambat kemunduran mutu ikan adalah dengan menghambat kerja enzim proteolitik menggunakan senyawa inhibitor alami termasuk yang berasal dari kulit ikan patin. Inhibitor katepsin diekstrak dengan baik pada saat ikan berada pada awal kematian atau fase pre rigor (Nurhayati \& Salamah, 2009). Nurhayati \& Salamah (2009) juga melaporkan hasil penelitiannya bahwa ikan bandeng yang disimpan pada suhu chilling tanpa ditambah inhibitor katepsin alami yang berasal dari ikan bandeng akan mengalami kemunduran mutu lebih cepat setelah melewati rigor mortis (ketika pH ikan 5) dibandingkan yang ditambahkan inhibitor katepsin alami tersebut. Nurhayati et al. (2011) juga melaporkan bahwa inhibitor katepsin alami dapat diaplikasikan pada ikan dari jenis yang berbeda dengan asal inhibitornya.

Inhibitor protease juga mempunyai manfaat untuk menghambat penurunan kekuatan gel. Hasil penelitian
Morrissey et al. (1996) menunjukkan bahwa penambahan inhibitor protease seperti sistatin pada surimi dapat mengurangi penurunan kekuatan gel melalui penghambatan protease sistein endogen. Inhibitor spesifik dari protease sistein sangat dibutuhkan untuk mencegah terjadinya proteolisis yang destruktif. Hasil penelitian yang telah dilakukan (Nurhayati et al., 2013) menunjukkan bahwa bagian daging ikan patin (Pangasianodon hypopthalmus) mengandung inhibitor protease. Informasi yang didapat dari penelitian ini memerlukan kajian lebih lanjut, oleh karena itu penelitian tentang ekstraksi inhibitor enzim katepsin dari kulit ikan patin perlu dilakukan.

Penelitian ini bertujuan untuk mengetahui potensi dari tiga jenis ikan patin sebagai bahan baku inhibitor katepsin dengan cara mengekstraksi dan mengkarakterisasi inhibitor katepsin dari kulit ikan patin terpilih.

\section{BAHAN DAN METODE}

\section{Bahan dan Alat}

Bahan utama yang digunakan pada penelitian ini adalah ikan patin jenis siam (Pangasianodon hypopthalmus), jambal (Pangasius djambal), dan pasupati (Pangasius sp.) dengan berat $\pm 350 \mathrm{~g}$ per ekor dan ukuran panjang $30-40 \mathrm{~cm}$, yang diambil bagian kulitnya pada kondisi segar. Bahan kimia yang digunakan untuk ekstraksi adalah buffer tris base (Applichem) $\mathrm{HCl}$ 0,1 M pH 7,4 dan akuades, untuk pemekatan adalah ammonium sulfat $\left(\mathrm{NH}_{4}\right)_{2} \mathrm{SO}_{4}$ teknis, untuk uji aktivitas katepsin dan inhibitor katepsin adalah hemoglobin (Sigma), buffer tris base (Applichem) $\mathrm{HCl}$ 0,1 M pH 7,4, tirosin (Applichem), akuades, asam trikloro asetat (TCA) $5 \%$ (Merck), folin (Merck), dan $\mathrm{HCl} 1 \mathrm{~N}$, sedangkan untuk uji kadar protein digunakan pereaksi Bradford, bovine serum albumin (BSA) Applichem.

Peralatan yang digunakan pada penelitian antara lain spektrofotometer UV-VIS RS UV-2500 dari LaboMed Inc, sentrifus suhu dingin (Himac CR7), inkubator (Thermoline tipe 42000 incubator), dan homogenizer.

\section{Metode}

Penelitian ini dilakukan melalui beberapa tahapan, yaitu preparasi bahan baku yang meliputi pengambilan kulit ikan patin, ekstraksi enzim katepsin (Dinu et al., 2002), ekstraksi inhibitor katepsin (An et al.,1995 yang dimodifikasi), pemekatan (Ustadi et al., 2005) yang dimodifikasi, dan karakterisasi inhibitor yang meliputi penentuan suhu dan $\mathrm{pH}$ optimum (Nurhayati et al., 2013). Pengujian aktivitas enzim katepsin dan 
aktivitas inhibitor enzim katepsin mengacu pada metode Dinu et al. (2002), dan uji kadar protein mengacu pada metode Bradford (1976) yang dimodifikasi. Tahapan penelitian disajikan pada Gambar 1.

\section{Ekstraksi enzim katepsin (Dinu et al., 2002)}

Ekstraksi dilakukan dengan preparasi sampel untuk memperoleh ekstrak kasar protease katepsin. Proses ekstraksi menggunakan ikan patin Siam yang sudah berada pada fase post rigor (sekitar12-15 jam penyimpanan pada suhu ruang). Daging ikan diambil dan disuspensikan dalam akuades dengan perbandingan daging ikan dan akuades sebesar 1:1, lalu dihomogenisasi pada suhu $0-4^{\circ} \mathrm{C}$.

Ekstrak daging hasil homogenisasi disentrifugasi pada $600 \mathrm{xg}$ selama 10 menit dan supernatan yang diperoleh kemudian disentrifugasi lagi pada 10.000 xg selama 10 menit. Pelet yang dihasilkan dari hasil sentrifugasi kemudian dilarutkan dalam $0,1 \mathrm{M}$ buffer tris- $\mathrm{HCl} \mathrm{pH} \mathrm{7,4} \mathrm{dengan} \mathrm{jumlah} \mathrm{yang} \mathrm{sama} \mathrm{seperti}$ jumlah akuades tadi dan disentrifugasi pada $4.000 \mathrm{xg}$ selama 10 menit. Hasil supernatan (ekstrak kasar protease katepsin) yang diperoleh merupakan substrat untuk pengujian aktivitas inhibitor katepsin.

\section{Ekstraksi inhibitor katepsin (An et al., 1995 yang dimodifikasi Rusyadi, 2010)}

Ekstraksi dilakukan terhadap bagian kulit patin (Siam, Jambal, dan Pasupati). Kulit ikan dipreparasi dari ikan patin yang masih berada pada fase pre rigor (sesaat setelah dimatikan). Sebanyak $100 \mathrm{~g}$ sampel dihomogenisasi dengan $100 \mathrm{ml}$ akuades dingin (dibawah $4^{\circ} \mathrm{C}$ ), selanjutnya disentrifugasi dingin pada kecepatan $5.000 \mathrm{xg}$ selama 30 menit. Supernatan diambil dan ditambahkan buffer Mcllvaine's pH 5,5 (dibuat dari 0,2 $\mathrm{M}$ sodium fosfat dan 0,1 M asam sitrat) dengan jumlah yang sama dengan supernatan. Kemudian diinkubasi selama 10 menit pada suhu $80^{\circ} \mathrm{C}$ selanjutnya disentrifugasi kembali pada kecepatan $7.000 \mathrm{xg}$ selama 15 menit. Supernatan diambil dan disimpan pada suhu dingin. Hasil ekstraksi



Gambar 1 Diagram alir produksi inhibitor katepsin.

Figure 1. Flow diagram of the production of cathepsin inhibitor. 
berupa ekstrak kasar inhibitor katepsin kemudian dianalisis aktivitasnya.

\section{Pemekatan Inhibitor Katepsin (Ustadi et al., 2005 yang dimodifikasi)}

Inhibitor katepsin yang mempunyai penghambatan tertinggi terhadap katepsin kemudian dipekatkan untuk meningkatkan aktivitasnya. Ekstrak kasar inhibitor katepsin dipekatkan menggunakan ammonium sulfat $\left(\left(\mathrm{NH}_{4}\right)_{2} \mathrm{SO}_{4}\right)$ dengan variasi tingkat kejenuhan 30,40, 50,60,70, dan 80\%mengikuti tabel teknik presipitasi ammonium sulfat (Bollag \& Edelstein, 1991). Pengendapan dilakukan dengan menambahkan garam ammonium sulfat ke dalam supernatan (ekstrak kasar inhibitor katepsin) sedikit demi sedikit. Campuran didiamkan selama semalam pada suhu sekitar $4^{\circ} \mathrm{C}$, selanjutnya disentrifugasi pada kecepatan $12.000 \mathrm{xg}$ selama 30 menit. Endapan dan supernatan dianalisis aktivitas inhibitor enzim katepsin dan konsentrasi protein.

\section{Karakterisasi inhibitor katepsin (Nurhayati et al., 2013)}

Karakterisasi inhibitor katepsin dilakukan terhadap endapan hasil pemekatan dengan ammonium sulfat. Karakterisasi meliputi penentuan suhu dan $\mathrm{pH}$ optimum. Analisis yang dilakukan adalah aktivitas inhibitor katepsin.

\section{Analisis aktivitas inhibitor katepsin (Dinu et al., 2002)}

Uji ini ditentukan dengan mengukur derajat penghambatan dari aktivitas enzim katepsin menggunakan substrat hemoglobin. Uji ini dimulai dengan mereaksikan ekstrak inhibitor $0,1 \mathrm{ml}$ dengan katepsin $0,1 \mathrm{ml}$ selama 30 menit pada suhu inkubasi $37^{\circ} \mathrm{C}$. Selanjutnya ditambahkan $0,5 \mathrm{ml}$ dari larutan substrat hemoglobin $2 \%$ (w/v) dan diinkubasi kembali pada $37^{\circ} \mathrm{C}$ selama 10 menit. Reaksi dihentikan dengan penambahan $2 \mathrm{ml} \mathrm{TCA} 5 \%(\mathrm{w} / \mathrm{v})$. Campuran disaring dan hasil reaksi ditambah dengan $1 \mathrm{ml}$ pereaksi folin, kemudian campuran diukur dengan spektrofotometer pada $\lambda=750 \mathrm{~nm}$.

Pengukuran ini dilakukan bersamaan dengan pengukuran larutan blanko dan larutan standar dengan prosedur yang sama seperti larutan sampel, hanya untuk larutan blanko larutan enzim digantikan dengan akuades dan untuk larutan standar, larutan enzim digantikan dengan tirosin. Bersamaan dengan itu juga dilakukan uji aktivitas katepsin tanpa penambahan inhibitor dengan menggunakan enzim katepsin sebanyak 0,1 ml. Aktivitas inhibitor dihitung berdasarkan perbedaan aktivitas enzim katepsin yang ditambah dengan inhibitor dan yang tanpa inhibitor.
Aktivitas enzim katepsin dapat dihitung dengan rumus sebagai berikut:

$$
\mathrm{UA}=\frac{\text { (Abs. sampel - abs. blanko) }}{\text { (Abs. standar - abs. blanko) }} \times \mathrm{P} \times \frac{1}{\mathrm{~T}}
$$

Keterangan/Note:

$\mathrm{UA} / \mathrm{mL}=$ jumlah tirosin yang dihasilkan per $\mathrm{ml}$ enzim per menit

$\mathrm{P} \quad=$ faktor pengenceran

$\mathrm{T} \quad=$ waktu inkubasi (10 menit)

Persentase penghambatan $=$

$1-\frac{\text { (Aktivitas katepsin dengan inhibitor) }}{\text { (Aktivitas katepsin tanpa inhibitor) }} \times 100 \%$

Satu unit inhibitor katepsin adalah jumlah inhibitor katepsin yang mampu menghambat aktivitas protease katepsin sebesar $50 \%$ pada kondisi pengujian.

\section{Analisis kadar protein (Bradford 1976 yang dimodifikasi)}

Konsentrasi protein ditentukan menggunakan metode Bradford dengan bovine serum albumin (BSA) sebagai standar. Persiapan pereaksi Bradford dilakukan dengan cara melarutkan $5 \mathrm{mg}$ coomassie brilliant blue G-250 dalam 2,5 ml etanol 95\% (v/v), lalu ditambahkan dengan $5 \mathrm{ml}$ asam fosfat $85 \%(\mathrm{v} / \mathrm{v})$. Jika telah larut dengan sempurna, maka ditambahkan akuades hingga $250 \mathrm{ml}$ dan disaring dengan kertas saring Whatman no. 1 dan diencerkan 5 kali sesaat sebelum digunakan.

Konsentrasi protein ditentukan dengan cara memasukkan 0,1 ml enzim ke dalam tabung reaksi, kemudian ditambahkan $5 \mathrm{ml}$ pereaksi Bradford, diinkubasi selama 5 menit dan diukur dengan spektrofotometer pada panjang gelombang $595 \mathrm{~nm}$. Demikian pula untuk larutan standar dilakukan sama seperti larutan sampel dengan mengganti larutan sampel dengan BSA pada konsentrasi antara 0,11$1,0 \mathrm{mg} / \mathrm{ml}$.

\section{HASIL DAN BAHASAN}

\section{Penghambatan Inhibitor Katepsin dari Tiga Jenis Kulit Ikan Patin}

Tahap ini diawali dengan ekstraksi enzim katepsin dari daging ikan patin Siam yang berada pada fase post rigor. Enzim katepsin yang dihasilkan mempunyai aktivitas $0,6 \mathrm{U} / \mathrm{ml}$. Untuk ekstraksi inhibitor katepsin, kulit ikan yang masih sangat segar digunakan mengacu pada teori yang telah 
disampaikan pada bagian pendahuluan. Persentase penghambatan enzim katepsin oleh inhibitor dari 3 jenis kulit ikan patin terhadap katepsin ikan patin Siam disajikan pada Gambar 2.

Ekstrak inhibitor dari kulit ikan patin jenis Siam mampu menghambat enzim katepsin tertinggi yaitu sebesar $74,67 \%$ dibandingkan dengan jenis Jambal dan Pasupati yaitu masing-masing sebesar $61,17 \%$ dan $65,00 \%$ (Gambar 2). Persentase penghambatan enzim katepsin oleh inhibitor yang tinggi pada kulit ikan patin Siam kemungkinan disebabkan oleh adanya kesesuaian antara substrat (enzim katepsin) dengan inhibitornya. Hal ini sesuai dengan prinsip kerja enzim atau inhibitor enzim yaitu mereka bekerja secara spesifik sehingga makin sesuai substratnya akan semakin tinggi aktivitasnya.

\section{Pemekatan menggunakan Ammonium Sulfat}

Ekstrak kasar inhibitor katepsin dari ikan patin jenis Siam yang diperoleh dipekatkan dengan teknik presipitasi berdasarkan teori salting out, menggunakan ammonium sulfat dengan konsentrasi kejenuhan $30 \%$ sampai $80 \%$. Tujuan pemekatan dengan ammonium sulfat ini adalah untuk menghilangkan sebagian protein pengotor yang

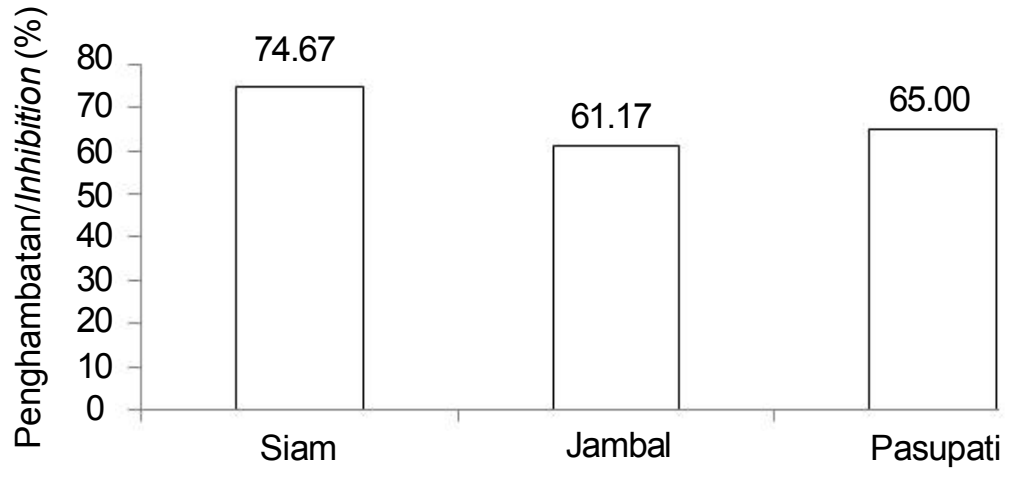

Jenis Ikan Patin/Type of Patin

Gambar 2. Penghambatan enzim katepsin oleh inhibitor dari kulit 2 spesies dan 1 hibrid kulit ikan patin terhadap katepsin ikan patin siam.

Figure 2. Cathepsin inhibition by inhibitor from 2 species and 1 hybrid of catfish different catfish skins against the cathepsin of siam patin.

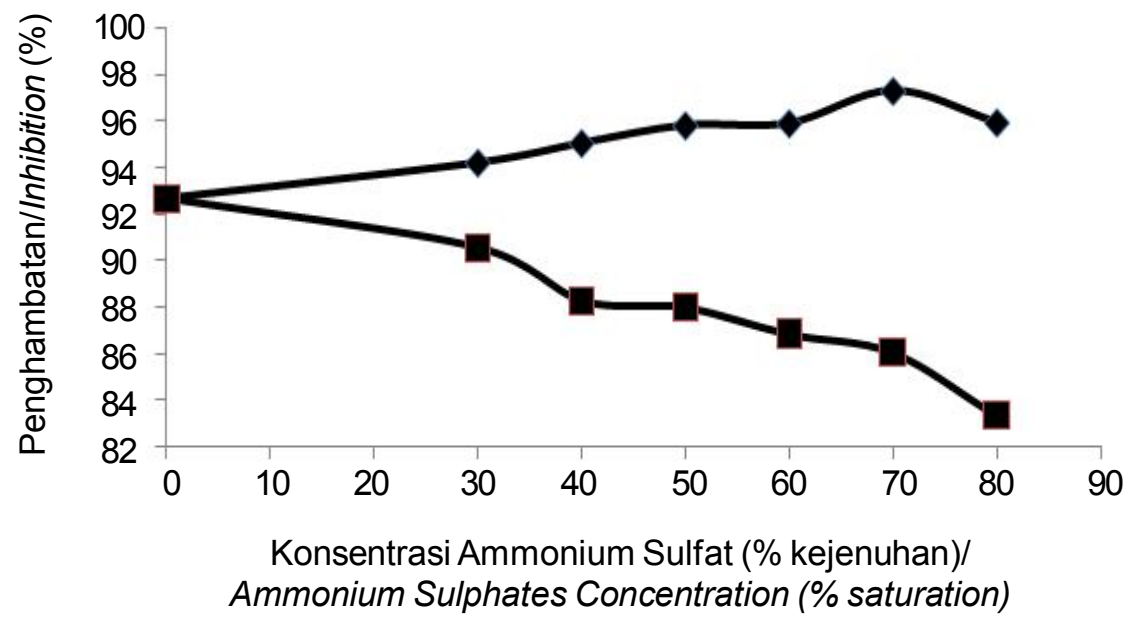

Gambar 3. Penghambatan katepsin oleh inhibitor kulit ikan patin setelah pengendapan ammonium sulfat, $\neg$-endapan, $\rightarrow$ - supernatan.

Figure 3. Cathepsin inhibition by inhibitor after ammonium sulphates precipitation $\neg$ pellet, $\rightarrow$ supernatan. 


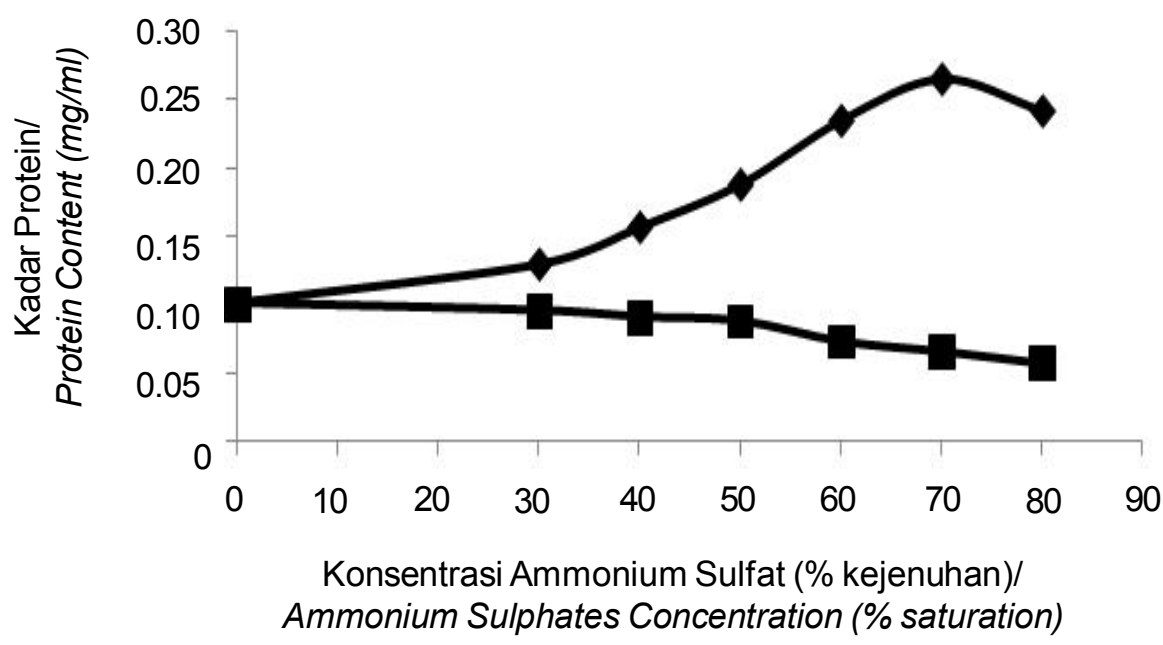

Gambar 4. Kadar protein terlarut setelah pengendapan ammonium sulfat, $\neg$ - endapan, $\rightarrow$ - supernatan. Figure 4. Dissolved protein content of cathepsin inhibitor after ammonium sulphates precipitation $\neg$ pellet, $\rightarrow$ - supernatan.

terdapat pada ekstrak kasar inhibitor katepsin tersebut sehingga inhibitor akan mempunyai persentase penghambatan yang lebih tinggi dibandingkan ekstrak kasar. Persentase penghambatan katepsin oleh inhibitor dari kulit ikan patin siam dan kadar proteinnya setelah pengendapan dengan ammonium sulfat disajikan pada Gambar 3 dan Gambar 4.

Persentase penghambatan katepsin oleh inhibitor pada bagian endapan mengalami peningkatan pada penggunaan konsentrasi ammonium sulfat yang semakin meningkat dan memiliki persentase penghambatan katepsin optimum pada penggunaan ammonium sulfat dengan tingkat kejenuhan $70 \%$. Presipitasi protein menggunakan ammonium sulfat dapat menyebabkan dehidrasi lingkungan mikro dari molekul protein. Ion-ion dari garam, seperti ion sulfat $\left(\mathrm{SO}_{4}{ }^{2-}\right)$ akan menarik dan mengikat molekul air dari koloid protein. Persentase penghambatan katepsin oleh inhibitor yang lebih rendah pada penggunaan ammonium sulfat dengan tingkat kejenuhan rendah disebabkan oleh proses salting in (Suhartono, 1989). Suhartono (1989) dan Rosenberg (1996) menyatakan bahwa penggunaan ammonium sulfat dengan tingkat kejenuhan rendah menyebabkan ion-ion ini akan mengisi lingkungan molekul protein sehingga protein melarut. Penggunaan ammonium sulfat dengan tingkat kejenuhan yang tinggi menyebabkan peningkatan muatan listrik yang akan menarik molekul air dari koloid protein sehingga interaksi hidrofobik diantara sesama molekul protein akan menurunkan kelarutan protein sehingga terjadi salting out yang menyebabkan protein terpresipitasi dan mengendap. Persentase penghambatan enzim katepsin oleh inhibitor pada bagian supernatan menunjukkan adanya penurunan dengan semakin meningkatnya kadar ammonium sulfat (Gambar 3). Hal ini disebabkan oleh semakin menurunnya protein inhibitor pada bagian supernatan akibat penggunaan ammonium sulfat dengan tingkat kejenuhan yang semakin tinggi.

Peningkatan persentase penghambatan katepsin oleh inhibitor pada endapan sejalan dengan peningkatan kadar protein. Ini menunjukkan bahwa protein yang terendapkan adalah berupa inhibitor katepsin. Kadar protein yang menurun pada supernatan juga sejalan dengan penurunan persentase penghambatan katepsin oleh inhibitor (Gambar 4).

Berdasarkan Gambar 3 dan 4 diperoleh informasi bahwa ekstrak kasar inhibitor katepsin dapat dipekatkan secara optimum dengan menggunakan ammonium sulfat $70 \%$ kejenuhan. Hasil ini sesuai dengan penelitian Rusyadi (2010) yang menunjukkan bahwa adanya peningkatan persentase penghambatan inhibitor enzim katepsin endapan pada beberapa tingkat konsentrasi ammonium sulfat dan mencapai aktivitas optimum pada endapan dengan konsentrasi ammonium sulfat $70 \%$.

\section{Produksi Inhibitor Katepsin}

Produksi dilakukan berdasarkan hasil terbaik dari penelitian tahap awal yaitu menggunakan kulit ikan patin jenis Siam yang diekstrak pada suhu inkubasi $80^{\circ} \mathrm{C}$ dan pemekatan menggunakan ammonium sulfat $70 \%$ kejenuhan.

Ekstrak kasar inhibitor katepsin yang dihasilkan dari kulit ikan patin mempunyai aktivitas $0,2 \mathrm{U} / \mathrm{ml}$ dengan konsentrasi protein $0,2450 \mathrm{mg} / \mathrm{ml}$ sehingga aktivitas spesifiknya sebesar 0,8163 U/mg. Ekstrak kasar selanjutnya dipekatkan dengan ammonium 
sulfat $70 \%(\mathrm{w} / \mathrm{v})$. Endapan yang dihasilkan dilarutkan dengan buffer Mcllvaine's 0,1 M pada pH 5,5. Endapan tersebut mempunyai aktivitas sebesar $0,6 \mathrm{U} / \mathrm{ml}$ dengan konsentrasi protein $0,2650 \mathrm{mg} / \mathrm{ml}$ sehingga aktivitas spesifik endapan tersebut adalah 2,2642 U/mg. Hasil ini menunjukkan peningkatan kelipatan pemurnian sebesar 2,77 kali. Ustadi et al. (2005) telah melakukan pemekatan inhibitor katepsin dari telur ikan glassfish tuna dengan menggunakan teknik yang sama dengan penelitian ini. Dengan pemekatan menggunakan amonium sulfat $40-80 \%$ kejenuhan, inhibitor katepsin dari telur ikan glassfish tuna tersebut yang semula memiliki aktivitas spesifik 3,97 U/mg menjadi meningkat sebanyak 3,38 kali. Rangkuman tahapan ekstraksi inhibitor katepsin hingga pemekatan disajikan pada Tabel 1 .

\section{Karakterisasi Inhibitor Katepsin}

\section{Suhu optimum}

Suhu optimum inhibitor enzim katepsin dari kulit ikan patin Siam adalah $40^{\circ} \mathrm{C}$. Hasil ini sama dengan suhu optimum inhibitor katepsin yang diekstraksi dari daging ikan patin Siam (Nurhayati et al., 2013). Inhibitor protease katepsin memiliki \% penghambatan maksimum pada suhu tertentu karena inhibitor ini diyakini adalah molekul protein. Persen penghambatan tersebut akan meningkat seiring dengan peningkatan suhu sehingga mencapai suhu optimum. Kenaikan suhu lebih lanjut akan menyebabkan penurunan penghambatan. Persen penghambatan inhibitor katepsin pada suhu yang berbeda disajikan pada Gambar 5.

Tabel 1. Tahap ekstraksi dan pemekatan inhibitor katepsin kulit ikan patin siam

Table 1. Stage of extraction and precipitation of cathepsin inhibitor from catfish skin

\begin{tabular}{lllccc}
\hline \multicolumn{1}{c}{ Tahap/Stage } & \multicolumn{1}{c}{$\begin{array}{c}\text { Produk/ } \\
\text { Product }\end{array}$} & $\begin{array}{c}\text { Aktivitas/ } \\
\text { Activity } \\
(\mathbf{U} / \mathbf{m l})\end{array}$ & $\begin{array}{c}\text { Konsentrasi } \\
\text { Protein/Protein } \\
\text { Concentration } \\
(\mathbf{m g} / \mathbf{m l})\end{array}$ & $\begin{array}{c}\text { Aktivitas Spesifik/ } \\
\text { Specific Activity } \\
\text { (U/mg) }\end{array}$ & $\begin{array}{c}\text { Kelipatan } \\
\text { Pemurnian (kali)/ } \\
\text { Purification Fold } \\
\text { (times) }\end{array}$ \\
\hline $\begin{array}{l}\text { Ekstraksi/ } \\
\text { Extraction }\end{array}$ & $\begin{array}{l}\text { Ektrak kasar/ } \\
\text { Crude extract }\end{array}$ & 0.200 & 0.245 & 0.816 & 1.000 \\
$\begin{array}{l}\text { Pemekatan } \\
\text { menggunakan } \\
\left(\mathrm{NH}_{4}\right)_{2} \mathrm{SO}_{4} 70 \% / \\
\text { Precipitation using } \\
(\mathrm{NH} 4)_{2} \mathrm{SO} 470 \%\end{array}$ & $\begin{array}{l}\text { Endapan yang } \\
\text { dilarutkan dalam } \\
\text { buffer/Pellet } \\
\text { dissolved by } \\
\text { buffer }\end{array}$ & 0.600 & 0.265 & & \\
\hline
\end{tabular}

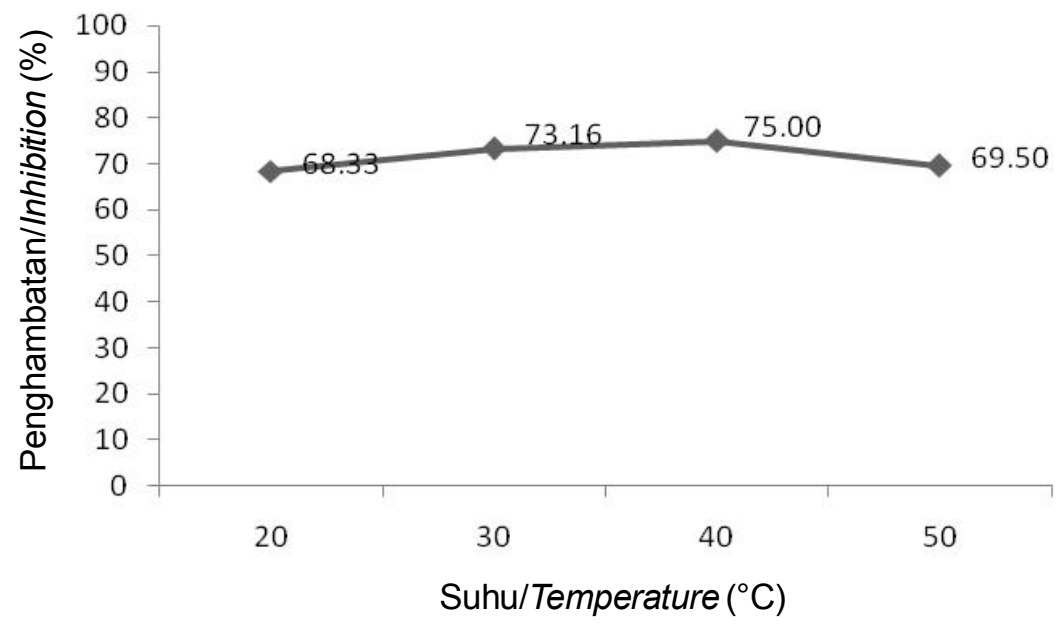

Gambar 5. Pengaruh suhu terhadap persen penghambatan inhibitor katepsin dari kulit ikan patin yang telah dipekatkan dengan ammonium sulfat $70 \%$ kejenuhan.

Figure 5. Effect of temperature on inhibitory activity of cathepsin inhibitor from catfish skin precipitated by ammonium sulphates $70 \%$ saturation. 


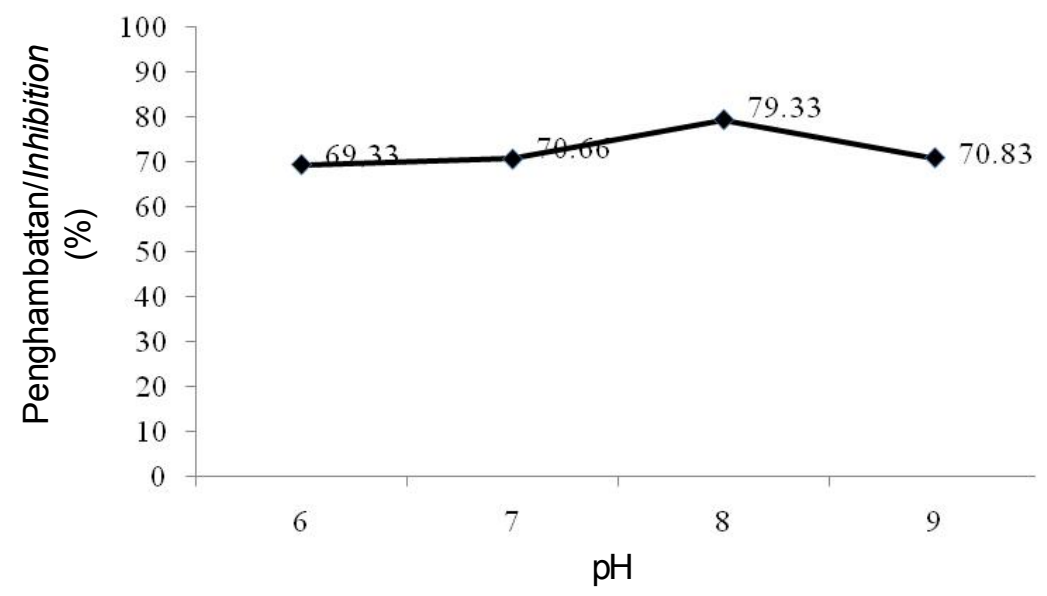

Gambar 6. Pengaruh $\mathrm{pH}$ terhadap persen penghambatan inhibitor dari kulit ikan patin yang diendapkan dengan ammonium sulfat $70 \%$ kejenuhan.

Figure 6. Effect of $\mathrm{pH}$ on inhibitoryactivity of cathepsin inhibitor from catfish skin which was precipitated by ammonium sulphates $70 \%$ saturation.

\section{pH optimum}

Setelah pengendapan dengan ammonium sulfat $70 \%$, inhibitor katepsin memiliki pH optimum 8. Semua reaksi enzim dipengaruhi oleh $\mathrm{pH}$ medium tempat terjadinya reaksi. Setiap enzim memiliki pH optimum yang khas, yaitu $\mathrm{pH}$ yang menyebabkan aktivitas maksimal. Perubahan persen penghambatan inhibitor protease terhadap aktivitas katepsin dapat terjadi akibat adanya perubahan ionisasi pada gugus ionik inhibitor pada sisi aktifnya maupun sisi lain yang secara tidak langsung mempengaruhi sisi aktif. Gugus ionik berperan dalam menjaga konformasi sisi aktif dalam mengikat substrat (enzim). Data mengenai pengaruh $\mathrm{pH}$ terhadap persentase penghambatan inhibitor katepsin disajikan pada Gambar 6.

Inhibitor katepsin ini memiliki pH optimum berada pada kisaran $\mathrm{pH}$ 7-9 (Gambar 6) yang menunjukkan bahwa ekstrak inhibitor katepsin termasuk inhibitor protease alkalin atau bersifat basa. Penelitian lain menunjukkan bahwa inhibitor protease seperti sistatin mempunyaipenghambatan pada kisaran $\mathrm{pH}$ alkalin. Penelitian Ustadi et al. (2005) menunjukkan bahwa ekstrak inhibitor protease dari telur ikan glassfish mempunyai aktivitas penghambatan yang tinggi pada kisaran $\mathrm{pH}$ 7-9 dan optimum pada $\mathrm{pH}$ 8. Penelitian oleh Li et al. (2008) menunjukkan bahwa inhibitor sistein protease dari plasma ikan chum salmon menunjukkan aktivitas penghambatan pada $\mathrm{pH} \mathrm{6-9}$ dan optimum pada $\mathrm{pH} 7$.

\section{KESIMPULAN}

Kulit ikan patin siam berpotensi sebagai bahan baku inhibitor enzim katepsin pada daging ikan patin siam, jambal dan pasupati. Penghambatan enzim katepsin tertinggi dicapai oleh inhibitor dari kulit ikan patin Siam. Penambahan ammonium sulfat dengan tingkat kejenuhan $70 \%$ ke dalam ekstrak kasar inhibitor mampu meningkatkan kemurnian sebesar 2,77 kali. Inhibitor katepsin tersebut memiliki penghambatan optimum pada suhu $40^{\circ} \mathrm{C}$ dan $\mathrm{pH} 8$.

\section{DAFTAR PUSTAKA}

An, H., Peters, M.Y., Seymour, T.A., and Morissey, M.T. 1995. Isolation and activation of chatepsin L-inhibitor complex from pacific whiting (Merlucciusproductus). J.Agric.Food Chem. 43: 327-330.

Aoki, T., Yamashita, T., and Ueno, R. 2000. Distribution of cathepsins in red and white muscles among fish species. J. Fish. Sci. 66(4): 776-782.

Bollag D.M. and Edelstein S.J. 1991. Protein Methods. A John Willey \& Sons Inc. Publication

Bradford, M.M. 1976. A rapid and sensitive method for quantification of microgram quantities of protein utilizing the principle of protein dye binding. Anal.Biochem. 72: 234-254.

Dinu, D., Dumitru, I,F., and Neichifor, M.T. 2002. Isolation and characterization of two chatepsin from muscle of Carrassius auratus gibelio. Roumanian Biotechnol. Lett. 7(3): 753-758.

Huss, H.H. 1995. Quality and Quality Changes in Fresh Fish. Food and Agriculture Organization of the United Nations, Rome. 348 p.

Li, D.K., Lin, H., and Kim, S.M. 2008. Purification and characterization of sistein protease inhibitor from chum salmon (Oncorhynchusketa) plasma. J. Agric. Food Chem. 56: 106-111.

Kolodziejska, I. and Sikorski, Z.E. 1996. Neutral and alkaline muscle proteases of marine fish and invertebrates -A review.J. Food Biochem. 20: 349363. 
Morrissey, M.T., Hartley, P.S., and An, H. 1996. Proteolytic activity in pacific whiting and effect of surimi processing.J. Aquatic Food Product. Technol. 4(4): 518.

Nurhayati, T. dan Salamah, E. 2009. Penghambatan kemunduran mutu ikan bandeng (Chanos chanos) dengan melibatkan inhibitor protease alami. Laporan Penelitian. Institut Pertanian Bogor, Bogor. $70 \mathrm{p}$.

Nurhayati, T., Salamah, E., dan Fentiana, N. 2010. Peranan enzim protease jeroan ikan bandeng (Chanos chanos) dalam proses kemunduran mutu ikan. Prosiding Seminar Nasional Pengolahan Produk dan Bioteknologi Kelautan. p. 25-34.

Nurhayati, T., Salamah, E., Irfan, M., dan Nugraha, R. $2010^{\mathrm{b}}$. Aktivitas enzim katepsin dan kolagenase pada kulit ikan bandeng (Chanos chanos, Forskal) selama periode kemunduran mutu. Akuatik. 4(1): 30-34.

Nurhayati, T., Salamah, E., Komariah, T., dan Apriland, A. 2011. Peranan inhibitor katepsin dari ikan patin (Pangasius hyphopthalmus) untuk menghambat kemunduran mutu ikan bandeng (Chanos chanos Forskal). JPHPI XIV. (1): 49-55.

Nurhayati, T., Rusyadi, S., Suwandi, R., and Nugraha, R. 2013. Purification and characterization of acathepsin inhibitor from catfish (Pangasius sp.) of Indonesian water. IFRJ. 20(2): 941-946.

Rosenberg, I.M. 1996. Protein Analysis and Purification: Benchtop technique. Birkhauser, Boston. 520 p.

Rusyadi, S. 2010. Purifikasi dan Karakterisasi Inhibitor Katepsin dari Ikan Bandeng (Chanos chanos Forskal) dan Ikan Patin (Pangasius sp.). Tesis. Sekolah Pascasarjana, Institut Pertanian Bogor, Bogor. 56 p.

Salamah, E., Nurhayati, T., and Rustamaji. 2010. Aktivitas enzim katepsin dan kolagenase pada ikan bandeng (Chanos chanos) selama periode kemunduran mutu. Logika. 7(2): 73-79.

Suhartono, M.T. 1989. Enzim dan Bioteknologi. PAU Bioteknologi IPB, Bogor.

Ustadi, Kim, K.Y., and Kim, S.M. 2005. Purification and identification of a protease inhibitor from glassfish (Liparistanakai) eggs. J.Agric. Food Chem. 53: 76677672 . 